\title{
Taxonomic differences between Pinus sylvestris and $P$. uncinata revealed in the stomata and cuticle characters for use in the study of fossil material
}

\author{
Salvia García Álvarez ，Carlos Morla Juaristi , Joaquín Solana Gutiérrez , Ignacio García-Amorena \\ Unidad Docente de Botánica, Escuela Técnica Superior de ingenieros de Montes, Universidad Politécriça de Madrid, Spain \\ Unidad Docente de Estadística, Escuela Técnica Superior de Ingenieros de Montes, Universidad Politécnica de Madrid, Spain
}

Keywords:

plant taxolnomy

plant variation

Iberian Peninsula

epidermal characteristics

needles

Pinus

\begin{abstract}
A B S T R A C T
Taxonomic differences in the needle epidermis characteristics of Pinus sylvestris $\mathrm{l}$. and Pinus uncinata Ramond ex DC. from two lberian populations were sought; such information could help identify these species when pollen analysis and the inspection of wood anatomy fails. The features of the cuticle are commonly well preserved in the fossil record. Although the epidermal patterns of the examined taxa were similar, qualitative differences were seen in the subsidiary and guard cells. P. sylvestris showed small subsidiary cells homogenously arranged around the opening of the epistomatal chamber, while $P$. uncinata showed small, lateral subsidiary cells and nondifferentiated subsidiary cells in the polar position. The aperture of the epistomatic chamber of $P$. uncinata was also larger in diameter ( $15.1 \pm 1.8 \mu \mathrm{m} P$. sylvestris; $21.1 \pm 2.8 \mu \mathrm{m} P$. uncinata). Principal components analysis and discriminant analysis was perfomed on the features of the guard cells characterising the size and shape of the cuticular thickenings - all the variables analysed can be measured in disperse stomata in microscope preparations for pollen analysis. Significant differences were found in the upper woody lamellae width and the coefficient associated with the shape of the medial lamellae borders (discriminant analysis weighting 0.739 and 0.826 respectively). Other significant parameters included the coefficient associated with the relative size of the medial lamellae border width of the guard cells with respect to the distance between the extemal limits of the medial lamellae borders, and the length of the upper woody lamella. Different light regimens appeared not to significantly affect the variability of the studied features.
\end{abstract}

\section{Introduction}

The cuticle preserves epidermal features of the leaf that are potentially important from a taxonomic point of view (Florin, 1939; Stace, 1965; Theobald et al., 1979; Kerp, 1990). The analysis of the shape and arrangement of the epidermal cells and other foliar structures such as trichomes and papillae has provided new evidence for phylogenetic and taxonomic discussion (Alvin et al., 1980; Barrón and Buades, 2002). Cuticle analysis has been used to revise the phylogeny of the genus Pinus $\mathbf{L}$. and to classify it into sections, subsections and subgenera (Yoshie and Sakai, 1985; Kim et al., 1999; Whang et al., 2001, 2004).

Owing to the cuticle's strong resistance to degradation, its structures are frequently well conserved in samples from palaeobotanical sites (Florin, 1939; Stace, 1965; Boulter, 1971; Theobald et al., 1979; Kerp, 1990). This, has led to substantial interest in its study. The analysis of cuticles is of particular value in the case of Pinus, as pollen commonly does not allow identification at the species level in this genus (Huntley and Birks, 1983). In addition, wood anatomy often cannot be used to distinguish between Pinus sylvestris L. and Pinus uncinata Ramond ex DC. (Schweingruber, 1990). The importance of the genus Pinus in the forest dynamics of Iberia's vegetation history is relatively well known, but our knowledge of the actual species involved remains poor. Taxonomic precision with respect to fossil Pinus material, however, is of considerable palaeophytogeographic interest (Bennett and Parducci, 2006). The identification of species in the fossil record via the analysis of needle fragment cuticles and isolated stomata may help reveal forest history and the dynamics of species distribution in more detail.

Peat sediments used in palynological investigations commonly harbour the remains of cuticles belonging to trees of the genus Pinus (Del Río Merino, 2000; Rubiales et al., 2007). Analysis of these remains allows the identification of subsidiary cells of the stomatal complex, and reveals the structure and dimensions of the aperture of the epistomatic chamber (pore). Moreover, isolated stomata are frequently preserved in palynological preparations (Aubert et al., 2004; Franco Múgica et al., 2001). Fossil remains of both types have been found at palaeobotanical sites in the mountains of southwestern Europe (Del Río Merino, 2000; Aubert et al., 2004). In this area, $P$. sylvestris and/or $P$. uncinata were abundant throughout the Quaternary. Being able to identify these species from their stoma 
and/or cuticle characteristics would improve the interpretation of palynological and palaeobotanical datasets.

Any study on the morphological characteristics of widespread species, such as P. sylvestris (Gaussen et al., 1964; Farjon, 1984), will necessarily run into difficulties when it tries to be complete and rigorous. However, if the information provided by local or regional studies is integrated with that of studies from other areas of Europe that used the same methodology (e.g., those of Stružková, 2002; Sweeney, 2003), conclusions can be reached that are applicable to extensive territories. The selection of $P$. syivestris and $P$. uncinata for the present study is the consequence of their being the only two Pinus species compatible with the environmental conditions prevailing in the high mountain areas of the Iberian Peninsula after the Wurmian glacial maximum (Costa et al., 1997). Palaeoremains that can be analysed are found in these areas (Rubiales et al., 2007; Turner and Hannon, 1988).

The aim of the present investigation was to examine the diagnostic value of the epidermal features of the needles of contemporary $P$. syivestris and $P$ uncinata, such as the stomatal complex, the subsidiary cells, the epistomatic chamber and the cuticular thickening of the guard cells, and to assess the possibility of using these to distinguish the species represented in fossil materials.

\section{Materials and methods}

\subsection{Material and pilot study}

The studied material came from two natural Iberian populations (see Fig. 1 and Table 1). A pilot study was undertaken on 30 pine needles collected from one tree of each population to determine the number of needles required from each tree in the full study. In this pilot study the stability of variance was determined using the artificial sampling techniques of Efron (1982). The optimum sample size for the set of variables was set to a maximum error of 5\%; significance was set at $P<0.01$ (Hansen et al., 1953). The pilot study also verified the possible influence of light conditions on the examined variables by comparing 15 needles from the sunny and 15 from the shady sides of the crowns of the two sampled trees. Analysis of variance (ANOVA) was performed for each variable taking into account the sun/shade factor.

Eighteen measurements for each variable were taken on one needle per population to determine the optimum number of measurements required; this was performed in a manner similar to that followed for calculating the number of needles required from each tree.

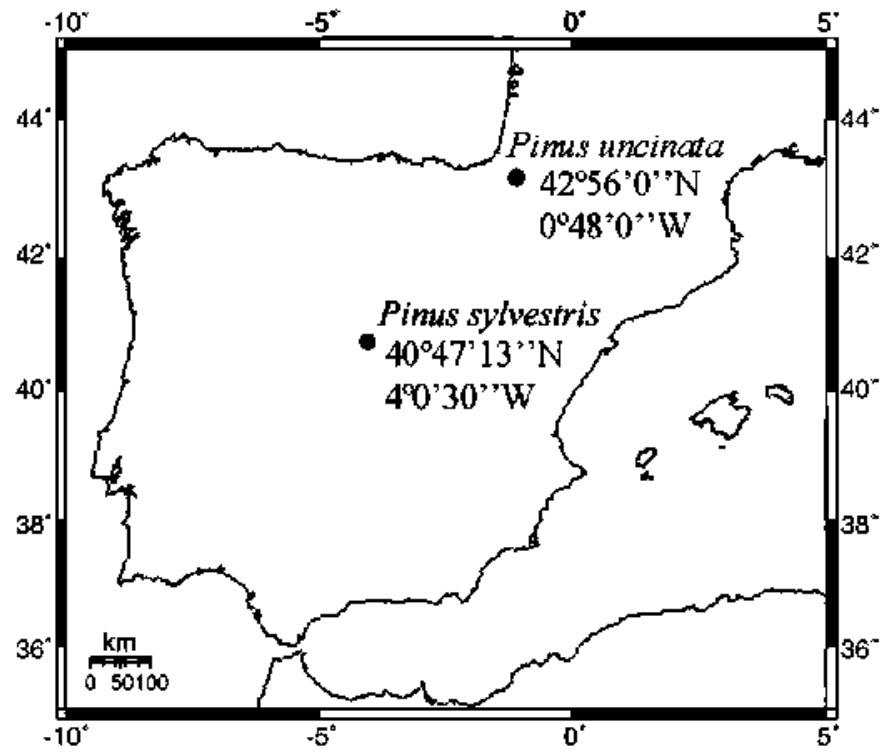

Fig. 1. Map of the Iberian Peninsula showing the populations sampled.
Table 1

Sampled populations. Region of Origin (Catalăn Bachiller, 1991; Martín Albertos et al., 1998). DBH: Breast Hight Diameter of the sample individuals. C. Age: Calculated age (Madrigal Collazo et al., 1999; Serrada Hierro et al., 2008).

\begin{tabular}{llllll}
\hline Species & Region of origin & Population & $\begin{array}{l}\text { Geographic } \\
\text { coordinates }\end{array}$ & $\begin{array}{l}\text { DBH } \\
\text { (cm) }\end{array}$ & $\begin{array}{l}\text { C. Age } \\
\text { (years) }\end{array}$ \\
\hline Pinus sylvestris & Guadalrama Range & $\begin{array}{l}\text { Navacerrada } \\
\text { (Madrid-Segovia) }\end{array}$ & $\begin{array}{l}40^{\circ} 47^{\prime} 13^{\prime \prime} \mathrm{N} \\
4^{\circ} 0^{\prime} 30^{\prime \prime} \mathrm{W}\end{array}$ & $>70$ \\
Pinus uncinata & Cental Pylenees & Larra (Navarra) & $\begin{array}{l}42^{\circ} 56^{\prime} 0^{\prime \prime} \mathrm{N} \\
0^{\circ} 48^{\prime} 0^{\prime \prime} \mathrm{W}\end{array}$ & $>30$ & $>100$ \\
\hline
\end{tabular}

Six additional trees of the same characteristics as in the pilot study were eventually sampled in each population (Table 1 ).

\subsection{Cuticle preparation}

For the preparation of cuticles, a 5 mm-long fragment was cut from the middle third of each needle. These fragments were boiled in water for one hour to eliminate the epicuticular waxes; they were then macerated in Schultz's solution (Kerp, 1990). After manually removing the remains of the mesophyll and part of the hypodermis, the fragments' cuticles were mounted on microscopic slides for examination by transmitted light microscopy. To examine the influence of acetolysis (a common palynological technique) on the variables measured, this was performed on three needles from each population following the method of Faegri and Iversen (1989). Cuticular and stomatal analyses were performed by examining photographs at a magnification of $\times 600$. Image Pro-Plus (IPP4) software was used to compare the variables examined.

\subsection{Analysis of the cuticle}

The cuticles were subjected to qualitative and quantitative analyses. The former involved the observation of the epidermal cells and the stomatal apparatus as a whole. The shape and arrangement of the subsidiary cells within each stomatal complex were examined, as was the shape of the pore. Quantitative analysis centred on measuring the diameter of this aperture (Fig. 2). The recorded values were subjected to ANOVA to determine the influence of the factor 'species'.

\subsection{Analysis of stomata}

This involved characterisation of the size and shape of the cuticular thickening of the guard cell walls. Based on the work of other authors (Hansen, 1995: Sweeney, 2003) and on preliminary observations of the collected samples, 11 variables were identified for measurement (the terminology employed is that of Florin (1931), Trautmann (1953) and Hansen (1995); see Appendix A for further information). Five coefficients were also calculated owing to their theoretical independence of stomatal size and environmental conditions (Tichá, 1982; Jones, 1992; García-Amorena et al., 2006). Table 2 shows all 16 stomatal variables measured.

The data obtained for each cuticle preparation in the final sample were subjected to principal components analysis (PCA) to determine the informative weight of each variable. Discriminant analysis was then performed to obtain a function capable of identifying needle fragments as either belonging to $P$. syivestris or $P$. uncinata. All calculations were performed using SPSS v14.0.1 or STATGRAPHICS (Centurión XV) software.

\section{Results}

The analysis of the stability of variance performed in the pilot study showed that five needles per tree were sufficient to cover the variability of the data with a confidence level of $90 \%$. For each pine 
needle the variance of the variables measured stabilised with less than ten measurements. Thus, to obtain reliable values for each variable, ten measurements were made on each of five needles from each of the six remaining trees per population.

\subsection{Influence of sun/shade}

Comparison of the needles from the sunny and shaded sides of the tree showed that the quantitative characteristics of their cuticles and stomata were very similar. ANOVA involving the factor sun/shade showed there to be no difference between the diameter of the pores, nor among 14 of the stomatal variables examined (level of confidence $99 \%)$. Significant differences were only seen between the sunny and shady needles in terms of the stomatal width $(A a)$ and the stem width (At) both in $P$. sylvestris and $P$. uncinata $(P<0.05)$.

\subsection{Cuticle characteristics}

The adaxial and abaxial surfaces were distinguishable due to the smaller width of the latter. The qualitative study of the cuticles of both species showed them to be morphologically very similar on both surfaces. The epidermis was composed of very elongated cells and the stomata arranged longitudinally in stomatal rows (Fig. 3). All stomata were sunken below the epidermal surface. The guard cells maintained contact with the exterior via the epistomatic chamber (Fig. 2C). Subsidiary cells totally or partially covered this chamber.

The stomatal complex provided the most taxonomic information. The subsidiary cells, the shape of the pore and the surrounding cuticular structures were different in the two species. The remaining epidermal cells were similar. Pimus sylvestris showed circular apertures for its epistomatic chambers, completely surrounded by a ring-like structure. Under the optical microscope this ring appeared to be formed by two small, elongated polar cells and between two and six even smaller, isometric lateral cells (Fig. 2A). Pinus uncinata showed subpolygonal apertures for its epistomatic chambers, the borders of which were marked by two to six isometric subsidiary cells, and, at the poles, two epidermal cells not differentiated from the remaining cells of the stomatal row (Fig. 2B).

ANOVA showed the size of the pores of the two species to be significantly different. Those of $P$. uncinata were larger (with a mean [standard deviation] of 21.05 [2.75] $\mu \mathrm{m}$ ) than those of $P$. sylvestris (15.06 [1.80] $\mu \mathrm{m}$ ) (Fig. 4). The 95\% confidence levels for the two species showed overlap between $15.54 \mu \mathrm{m}$ and $18.65 \mu \mathrm{m}$. Thus, with a probability of $95 \%$, values of $<15.54 \mu \mathrm{m}$ can be attributed to $P$. sylvestris while those of $>18.65 \mu \mathrm{m}$ can be attributed to P. uncinata. The uniformly most powerful test (UMP) (Rios, 1977) curve did not go below $91 \%$; the best decision threshold was $17.42 \mu \mathrm{m}$ (Table 3).

\subsection{Stomatal characteristics}

The qualitative study of the stomata of both species showed them to have similar qualitative features (Fig. 5). The lower woody lamella covered the entire lower periclinal wall of each guard cell. The upper woody lamella was thicker but less extensive than its lower counterpart. The stems were seen at the poles of the stomata. The thickening of the medial lamellae borders ran along the guard cells from stem to stem. A narrow, very little thickened outer wall was seen in the central part of the guard cells.

Statistical analysis of the 16 examined stomatal variables revealed significant differences between the species (see below).

\subsection{Principal components analysis}

PC1 showed stomatal differences that influenced taxonomic identification (Fig. 6). Fig. 7 shows the weight of each variable in
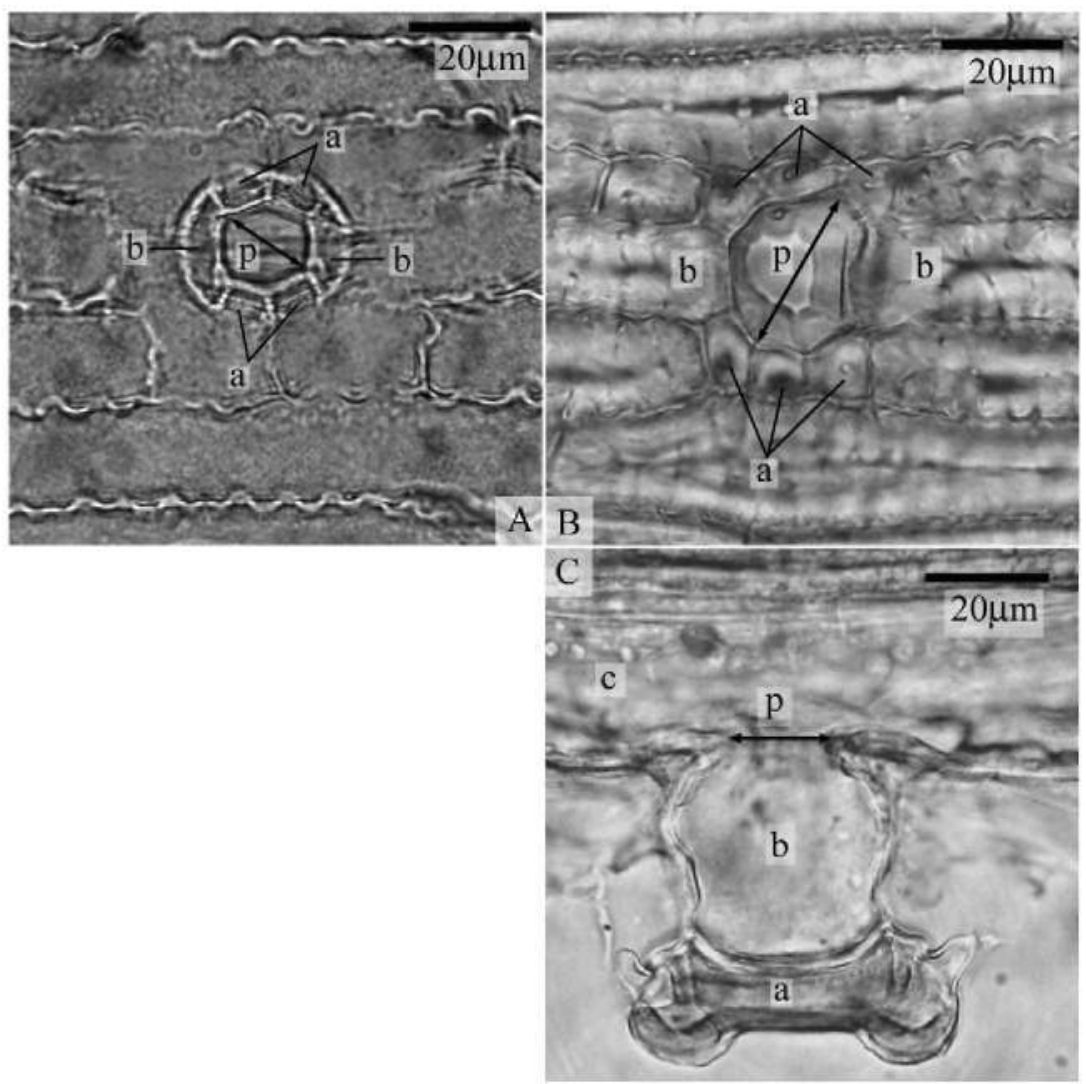

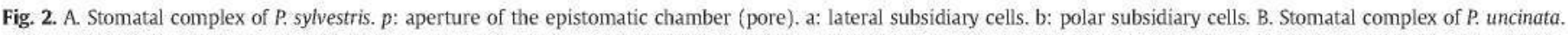

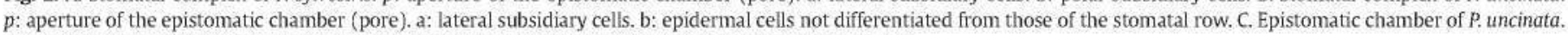
a: guard cell. b: epistomatic chamber. c: epidermal cells, p: aperture of the epistomatic chamber (pore). 
Table 2

Measured characters describing variation of size and shape of stomatal cuticular thickenings.

\begin{tabular}{|c|c|c|}
\hline Variables & & $\begin{array}{l}\text { Mentioned in } \\
\text { previous studies }\end{array}$ \\
\hline Stomatal width & $A a$ & Trautmann (1953) \\
\hline Stomatal length & La & $\begin{array}{l}\text { Trautmann (1953), } \\
\text { Sweeney (2003) }\end{array}$ \\
\hline Upper woody lamellae width & $A b$ & $\begin{array}{l}\text { Trautmann (1953), } \\
\text { Hansen (1995), } \\
\text { Sweeney (2003) }\end{array}$ \\
\hline Upper woody lamella length & $L b$ & $\begin{array}{l}\text { Trautmann (1953), } \\
\text { Hansen (1995), } \\
\text { Sweeney (2003) }\end{array}$ \\
\hline $\begin{array}{l}\text { Distance between the external limits } \\
\text { of the medial lamellae borders } \\
\text { measured at their centre }\end{array}$ & Ic & Yu (1997) \\
\hline $\begin{array}{l}\text { Distance between the external limits } \\
\text { of the medial lamellae borders } \\
\text { measured at the point } \\
\text { where both meet to form the } \\
\text { stem (see Appendix A for } \\
\text { the use of this term) }\end{array}$ & Id & \\
\hline Medial lamellae border width & $e$ & Sweeney (2003), Yu (1997) \\
\hline Stem length & Lt & Hansen (1995), Yu (1997) \\
\hline Stem width & At & $\begin{array}{l}\text { Hansen (1995), Yu (1997), } \\
\text { Sweeney (2003) }\end{array}$ \\
\hline $\begin{array}{l}\text { Angle of attachment of upper } \\
\text { woody lamella }\end{array}$ & alfa $(\alpha)$ & $\begin{array}{l}\text { Hansen (1995), } \\
\text { Sweeney (2003) }\end{array}$ \\
\hline $\begin{array}{l}\text { Angle between the stem and } \\
\text { medial lamella border }\end{array}$ & beta $(\beta)$ & Sweeney (2003) \\
\hline Coefficient of stomatal slimness ${ }^{a}$ & coef_a $a=A a / L a^{a}$ & \\
\hline $\begin{array}{l}\text { Coefficient of slimness of the } \\
\text { upper woody lamellae }\end{array}$ & $\begin{array}{l}\operatorname{coef}_{-} b=A b / \\
L b^{a}\end{array}$ & \\
\hline $\begin{array}{l}\text { Coefficient associated with the shape } \\
\text { of the medial lamellae border }\end{array}$ & $c o e f_{-} c=l c / l d^{a}$ & \\
\hline $\begin{array}{l}\text { Coefficient associated with the relative } \\
\text { size of the medial lamellae border } \\
\text { width of a guard cell with respect } \\
\text { to the distance between the external } \\
\text { limits of the medial lamellae border }\end{array}$ & coef_e $=l c / e^{\mathrm{a}}$ & \\
\hline Coefficient of slimness of the stem ${ }^{2}$ & $\operatorname{coef}_{-} T=A t / L t^{\mathrm{a}}$ & \\
\hline
\end{tabular}

a Recalculated variables.

this principal component. The upper woody lamellae width $(A b)$ and stomatal width $(A a)$ showed the greatest weights $(0.923$ and 0.921 respectively), followed by the coefficient of stomatal slimness (coef_a; 0.731 ), the coefficient associated with the shape of the medial lamellae borders (coef_c; 0.676), and the distance between the external limits of the medial lamellae borders measured at their centre $(l c ; 0.614)$. Together, these five variables accounted for $>60 \%$ of

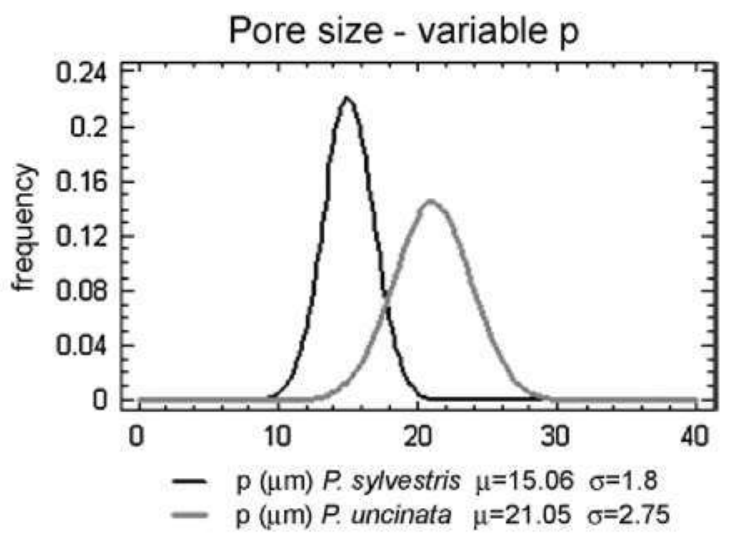

Fig. 4. Normal distributions of the populations obtained from data (means and SD) for the variable $p$ for both $P$. sylvestris and $P$. uncinata.

the variance of PC1. Strong linear relationships were seen between the stomatal width $(A a)$, the upper woody lamellae width $(A b)$, the coefficient of stomatal slimness (coef_a; with 0.71 the weakest correlation value), and between the coefficient associated with the shape of the medial lamellae borders (coef_c) and the distance between the external limits of the medial lamellae borders measured at their centre $(I c ; 0.57)$

Individual ANOVA of the upper woody lamellae width $(A b)$ and the coefficient associated with the shape of the medial lamellae borders (coef_c) confirmed their taxonomic usefulness (Figs. 8-10). For the population of $P$. sylvestris the mean $A b$ was 33.27 (2.37) $\mu \mathrm{m}$, and the mean coef_c was $0.99(0.08)$; for $P$. uncinata these figures were 39.08 (2.68) $\mu \mathrm{m}$ and $1.16(0.11)$ respectively.

\subsection{Discriminant analysis}

Discriminant analysis of the stomatal variables provided the following function:

Discriminant function $=0.739 \cdot A b+0.277 \cdot L b+0.826 \cdot$ coef $\_c-0.540 \cdot$ coef_e (Wilks $\Lambda=0.228 ; P=0.01$; relative error $2.54 \%$ ).

\section{Discussion}

The features of the stoma and cuticle structure observed were those generally used in descriptions of Pinus subgenus Pinus (Trautmann, 1953; Mirov, 1967; Esau, 1982; Yoshie and Sakai, 1985;

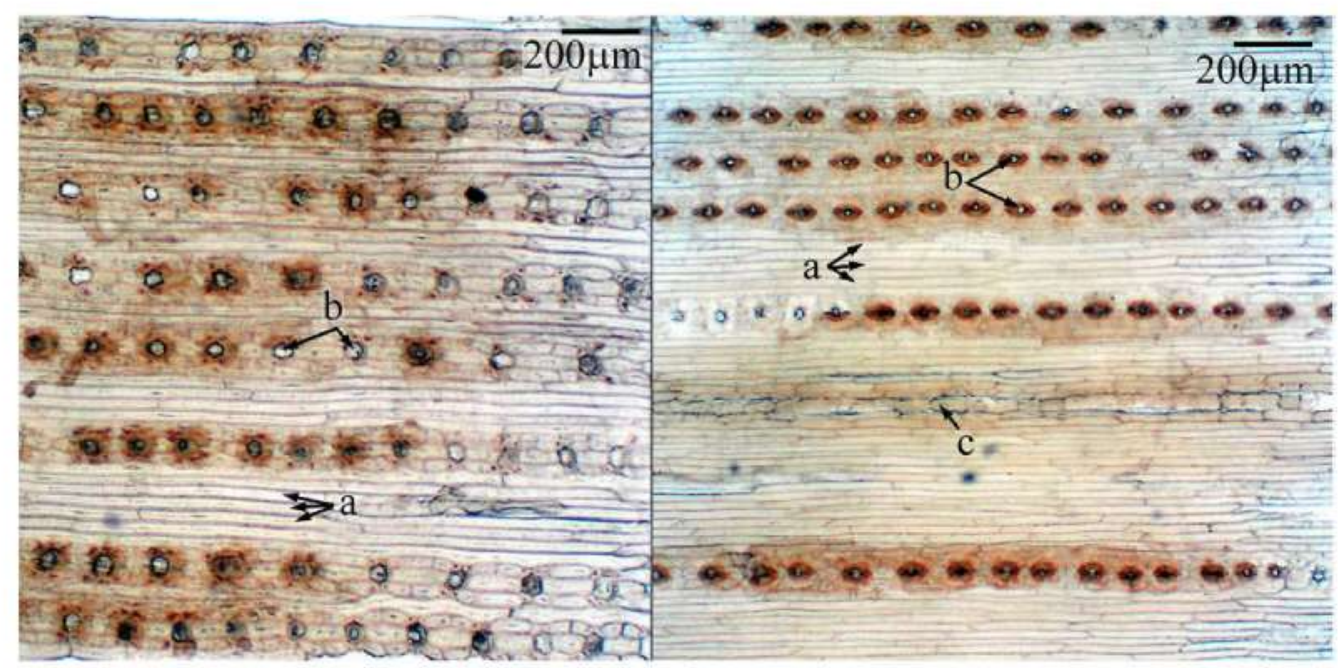

Fig. 3. Cuticles of $P$. uncinata (left) and $P$. sylvestris (right), a: non-differentiated epidermal cells. b: apertures of epistomatic chambers, c; needle tooth. 
Table 3

Measurement of the variables $p$ (diameter of the aperture of the epistomatic chamber), $A b$ (upper woody lamellae width) and coef $c$ (coefficient associated with the shape of the medial lamellae border) in the Iberian populations of $P$. sylvestris and $P$, uncinat $\alpha, x(\mu \mathrm{m})$ : mean. $\sigma(\mu \mathrm{m})$ : standard deviation. 95\% CI: 95\% confidence interval. P95: values within the $95 \%$ probability range of belonging to the population. UMP: the uniformly most powerful test shows the threshold of the uncertainty zone $(u)$ plus the maximum associated error (e).

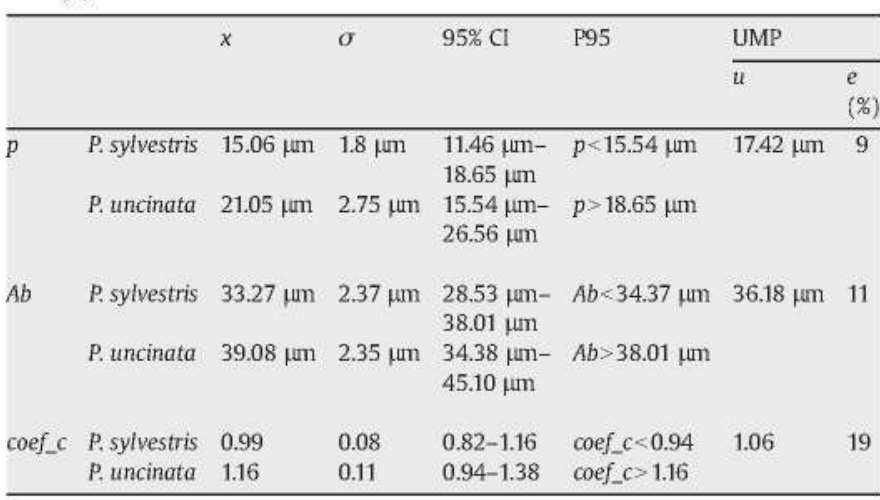

Hansen, 1995; Farjon and Styles, 1997; Sweeney, 2003). The present study, however, identified significant differences among some of these variables that allow $P$. sylvestris and $P$. uncinata to be distinguished.

The populational stability of the epidermal and stomatal features investigated strengthens their taxonomic diagnostic value. In addition, none of the studied characteristics, except for stem width (At) and stomatal width $(A a)$, were affected by the needles growing in the sun or in the shade.

\subsection{Characteristics of the cuticle}

In the studied populations, the epidermal cells outside of the stomatal complex were of no value in distinguishing between the two

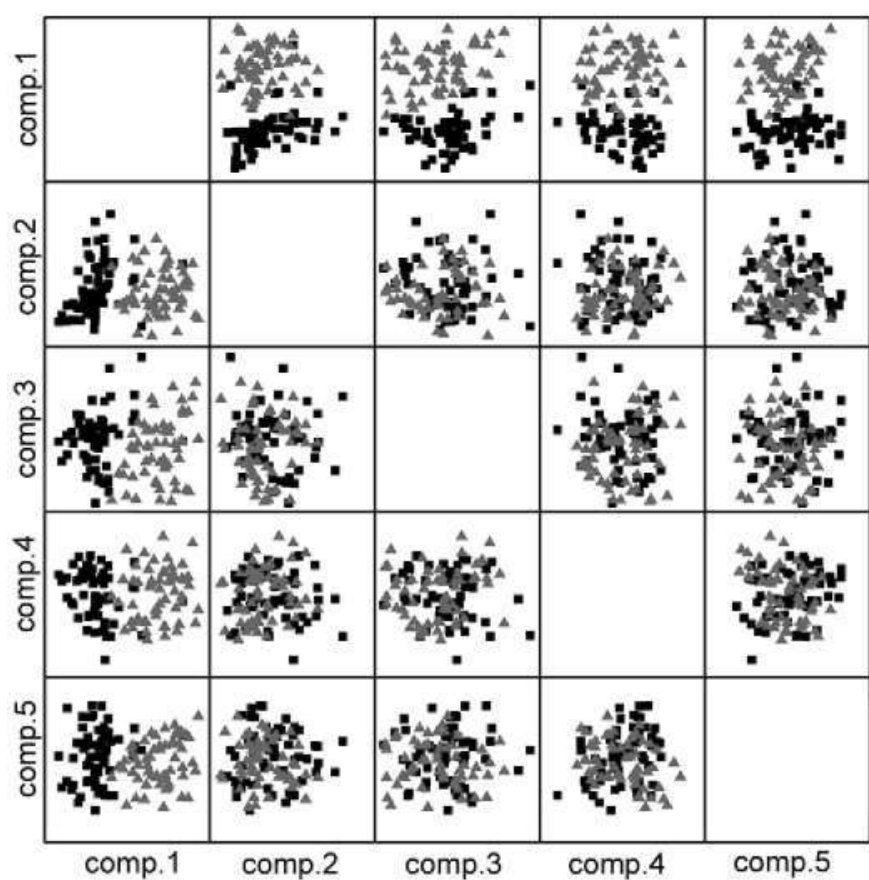

- $P$. sylvestris

$\triangle P$. uncinata

Fig. 6. Principle components diagram for needle variables. Each point represents the position of a single needle according to the values of the variables recorded (factors I-V).

species; this is also been reported by Boratynska and Bobowicz (2001). However, the shape and arrangement of the subsidiary cells of the stomatal complex and the shape of the pores and surrounding

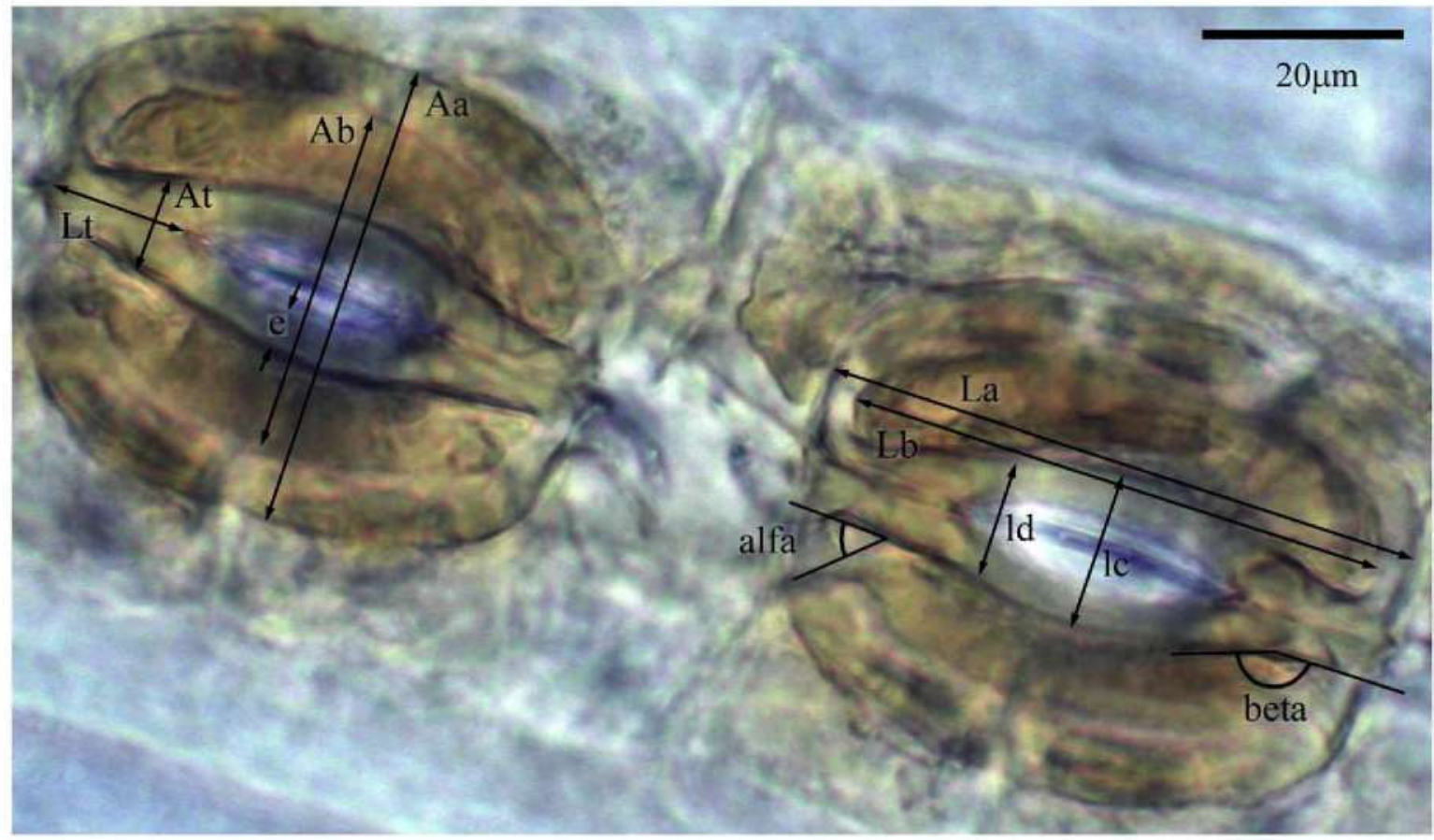

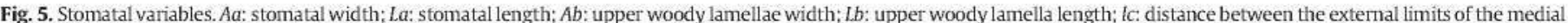

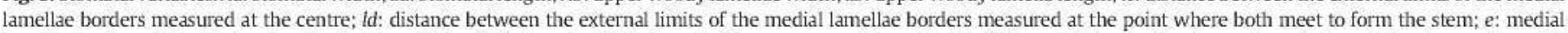

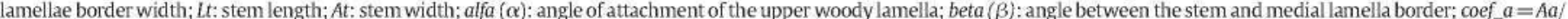

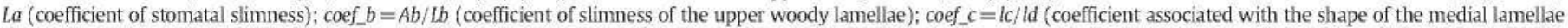

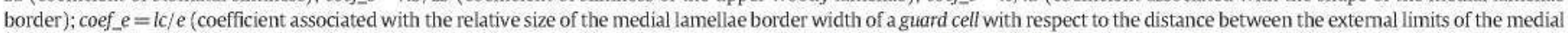
lamellae borders; coef $T=A t / L t$ coefficient of slimness of the stem. Terminology based on that of Florin (1931), Trautmann (1953) and Hansen (1995) (Appendix A). 


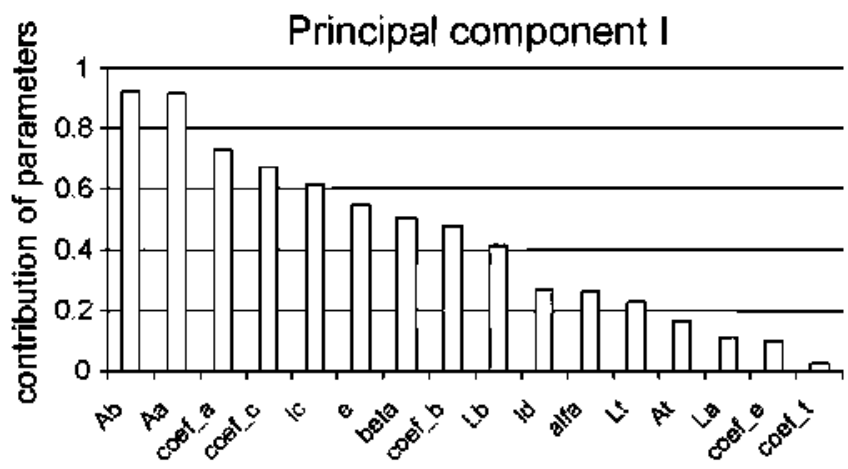

Fig. 7. Influence of every parameter in the first principal component. Component $\mathrm{I}=0.923 \cdot A b+0.921 \cdot A a+0.731 \cdot \operatorname{coe} f_{-} a+0.676 \cdot \operatorname{coe} f_{-} c+0.614 \cdot i c+0.550 \cdot e++$ $0.509 \cdot$ beta $+0.478 \cdot \operatorname{coef}_{-} b+0.417 \cdot \mathrm{Lb}-0.272 \cdot[d-0.265 \cdot \mathrm{alfa}+0.230 \cdot \mathrm{Lt}+0.167 \cdot \mathrm{At}++$ $0.112 \cdot L a-0.0998 \cdot c_{0} f_{-} e+0.02649 \cdot c_{0} f_{-} t$.

cuticular thickenings offered a reliable means of distinguishing between them.

The circular structure around the epistomatic chamber openings could be seen perfectly in all the P. sylvestris material studied, as reported for other European populations of this species (Stružková, 2002). This finding suggests this structure to be taxonomically stable within this taxon. In contrast, no such ring was seen in P. uncinata. The descriptions of the stomatal complexes of other taxa close to $P$. uncinata, e.g., $P$. mugo Turca, do not mention this feature either (Stružková, 2002), strengthening the idea that this element can be used to distinguish between $P$. syivestris and $P$. uncinata- $P$. mugo. In P. sylvestris the ring in question corresponds to the cuticular thickenings described by Florin (1931) for many species of Pinus (Florin ring). Later studies have emphasized the taxonomic importance of this ring. Six different types have been identified; four of them occur in the subgenus Pinus, of which one is seen in $P$. sylvestris (Yoshie and Sakai, 1985; Farjon and Styles, 1997; Kim et al., 1999; Whang et al., 2001. 2004).

The diameter of the aperture of the epistomatic chamber was also found to be useful for distinguishing between needles of $P$. syivestris

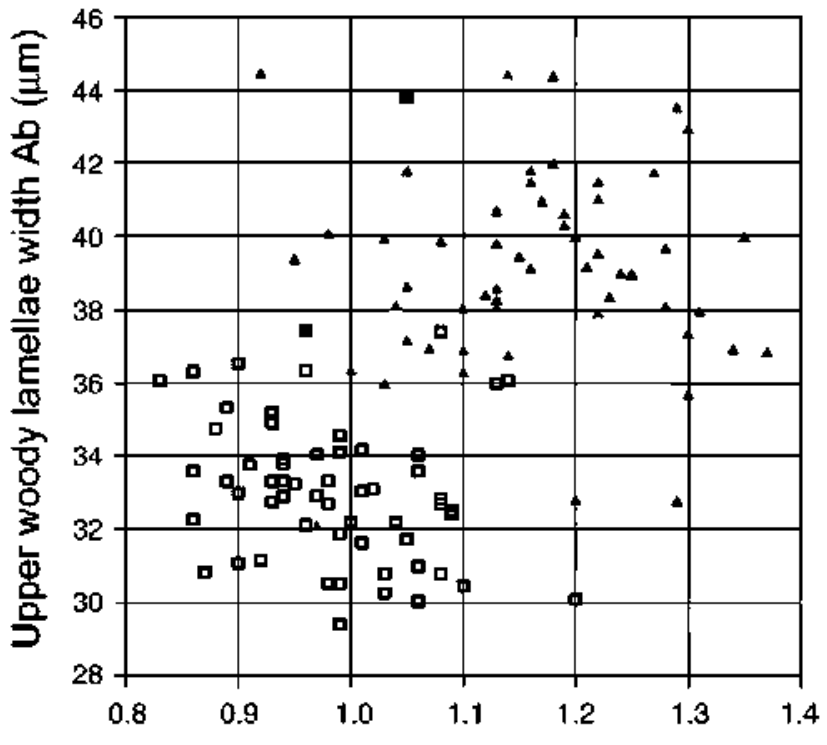

Medial lamellae border coeficient coef_c

- P. sylvestris

- P. uncinata

Fig. 8. Plot of upper woody lamellae width $(A b)$ values against coefficient associated with the shape of the medial lamellae border (coef_c) values for the studied needles.

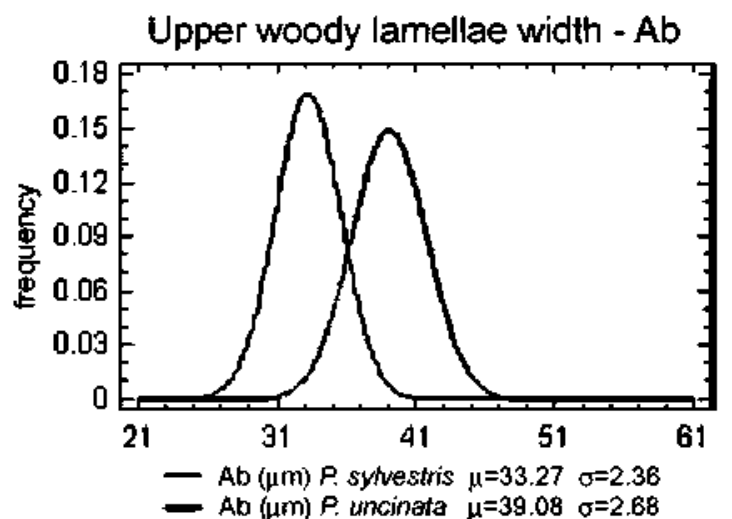

Fig. 9. Nomal distributions of the populations obtained from the data (means and SD) for the upper woody lamellae width $(A b)$ for both $P$. sylvestris and $P$, uncinata.

and $P$. uncinata (Fig. 4, Table 3). The values obtained for the $P$. syivestris population are around the mean for the European populations studied to date (Table 4) (Stružková, 2002), illustrating the intraspecific stability of this feature. No European references are available for $P$. uncinata. The values of the closest relative, $P$. mugo, are similar to those recorded for $P$. uncinata in the present study. Although the mean value for the European populations (Stružková, 2002) differs somewhat to those recorded in the present work for $P$. uncinata, it still falls within the normal range $(95 \% \mathrm{Cl})$.

The similarity in the appearance of the stomatal complex of $P$ uncinata and that described for $P$. mugo (Stružková, 2002) indicates the stability of this structure within the $P$. uncinata-P. mugo group. The similarity of the cuticular characteristics of $P$. uncinata and $P$. mugo reflects their close phylogeny and may support the grouping of these two taxa into a single species, Pinus montana Mill. (Mirov, 1967).

\subsection{Stomatal characteristics}

The general features of all the stomata observed in the present work were similar to those described by Trautmann (1953), Esau (1982), Hansen (1995) and Sweeney (2003) for the genus Pinus. The stomata of $P$. sylvestris and $P$. uncinata showed no qualitative differences. However, significant differences were detected between the stomatal variables defined.

Five variables were selected by PCA for their taxonomic value: the stomatal width $(A a)$, the upper woody lamellae width $(A b)$, the coefficient of stomatal slimness (coef_a), the coefficient associated with the shape of the medial lamellae borders $($ coef_c), and the

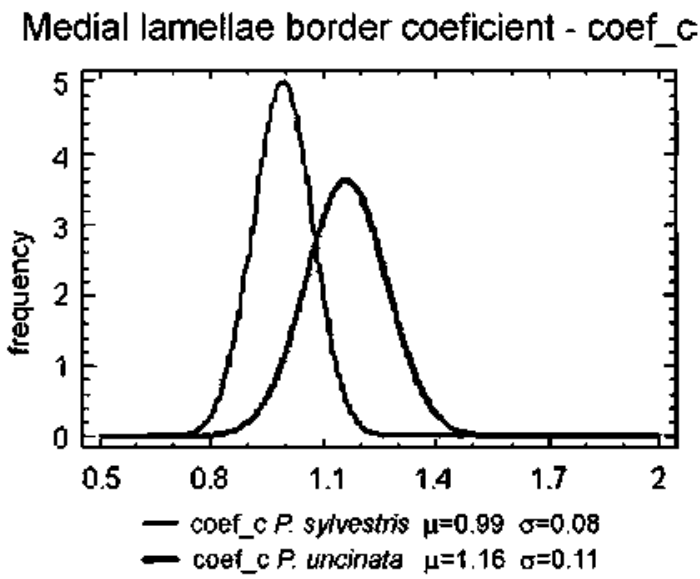

Fig. 10. Normal distributions of the populations obtained from the data (means and SD) for the coefficient associated with the shape of the medial lamellae border (coef_c) for both $P$. sylvestris and $P$. uncinata. 
distance between the external limits of the medial lamellae borders measured at their centre $(\mathrm{lc})$. Several redundant variables can be omitted because of their strong linear relationship. With respect to the upper woody lamellae width $(A b)$ and the stomatal width $(A a)$, the former is best maintained since it has the greatest weight in PC1 and is strongly correlated to stomatal width $(A a)$ and the coefficient of stomatal slimness (coef_a). Further, since this variable involves the upper woody lamellae, unlike Aa and coef_a which involve the lower woody lamellae, it is easier to measure in specimens degraded by acetolysis (Hansen, 1995). With respect to the coefficient associated with the shape of the medial lamellae borders $\left(\operatorname{coef}_{-} c\right)$ and the distance between the external limits of the medial lamellae borders measured at their centre ( $i c$ ), the former is a better identifying variable since it has a greater weight in PC1 and because $i c$ is more dependent on stomatal size.

Data provided by individual ANOVA and the normal distribution of the upper woody lamellae width $(A b)$ and the coefficient associated with the shape of the medial Iamellae borders (coef_c), allow boundaries to be established between these taxa. Upper woody lamellae width $(A b)$ values of $<34.37 \mu m$ identify $P$. sylvestris with a degree of confidence of $95 \%$, while those of $>38.01 \mu \mathrm{m}$ identify $P$ uncinata with the same degree of confidence. The UMP test showed the best decision threshold to be $36.18 \mu \mathrm{m}$, with a minimum power of $89 \%$ (Table 3). A value for the coefficient associated with the shape of the medial lamellae borders (coef_c) of $<0.94$ identifies $P$. sylvestris while $>1.16$ identifies $P$. uncinata (both at the $95 \%$ confidence level). Intermediate coef_c values do not distinguish between the species $(P>0.05)$, although the power of the 1.06 threshold returned by the UMP test was always greater than $81 \%$ (Table 3 ).

Discriminant analysis suggested the best variables for classifying an unknown stoma to be the upper woody lamellae width $(A b)$, the upper woody lamella length $(b b)$, the coefficient associated with the shape of the medial lamellae borders (coef_c), and the coefficient associated with the relative size of the medial lamellae border width of a guard cell with respect to the distance between the external limits of the medial lamellae borders (coef_e). A final value for the discriminant function of $<0$ identifies P. sylvestris (discriminant $F<0$ ), while a value of $>0$ identifies $P$. uncinata (error $2.54 \%$ ). The four mentioned variables $A b, L b$, coef_c and coef_e are measured with respect to the greatest thickenings of the guard cells. They were also easy to measure in material subjected to acetolysis. Thus they can be determined in both untreated fossils and palynoligically-treated material.

\section{Table 4}

Comparison of stomatal measurements for the two Iberian populations studied, plus data from other studies on European populations. $X(\mu \mathrm{n})$ : mean. $\sigma(\mu \mathrm{m})$ : standard deviation. $M(\mu m)$ : maximum value. in $(\mu m)$ : minimum value.

\begin{tabular}{|c|c|c|c|c|c|c|c|}
\hline & & \multicolumn{2}{|c|}{ Ibelian populations } & \multirow{2}{*}{$\begin{array}{l}\text { Hansen } \\
(1995) \\
\begin{array}{l}\text { Geluus } \\
\text { Pinus }\end{array}\end{array}$} & \multirow{2}{*}{$\begin{array}{l}\text { Sweeney } \\
(2003) \\
\text { Pinus } \\
\text { sylvestris }\end{array}$} & \multicolumn{2}{|c|}{ Snužková (2002) } \\
\hline & & $\begin{array}{l}\text { Pinus } \\
\text { sylvestris }\end{array}$ & $\begin{array}{l}\text { Pinus } \\
\text { uncinata }\end{array}$ & & & $\begin{array}{l}\text { Pinus } \\
\text { sylvestris }\end{array}$ & $\begin{array}{l}\text { Pinus } \\
\text { mugo }\end{array}$ \\
\hline \multirow[t]{2}{*}{$\overline{A b \text { (un) }}$} & $x$ & 33.27 & 39.08 & & 24.60 & & \\
\hline & $\sigma$ & 2.37 & 2.68 & & 1.71 & & \\
\hline \multirow[t]{2}{*}{ At $(\mu \mathrm{m})$} & $x$ & 13.23 & 13.13 & & 729 & & \\
\hline & $\sigma$ & 1.93 & 1.39 & & 0.48 & & \\
\hline \multirow[t]{2}{*}{$e(\mu m)$} & $x$ & 3.37 & 3.82 & & 5.04 & & \\
\hline & $\sigma$ & 0.34 & 0.42 & & 1.28 & & \\
\hline \multirow[t]{2}{*}{$L b(\mathrm{un})$} & $x$ & 53.27 & 57.94 & & 38.45 & & \\
\hline & $\sigma$ & 5.62 & 4.50 & & 3.28 & & \\
\hline \multirow[t]{2}{*}{ La (un) } & $x$ & 68.74 & 69.74 & & 44.55 & & \\
\hline & $\boldsymbol{\sigma}$ & 4.49 & 4.01 & & 3.75 & & \\
\hline \multirow[t]{2}{*}{ angle $\alpha$} & $m$ & $22.34^{\circ}$ & $18.37^{\circ}$ & $20^{\circ}$ & & & \\
\hline & $M$ & $48.50^{\circ}$ & $48.66^{\circ}$ & $30^{\circ}$ & & & \\
\hline \multirow[t]{2}{*}{$c 0 e f_{-} b$} & $x$ & 0.63 & 0.68 & & 0.64 & & \\
\hline & $\sigma$ & 0.07 & 0.08 & & & & \\
\hline \multirow[t]{3}{*}{$p($ lun $)$} & $m$ & 11.06 & 14.29 & & & 6.25 & 10 \\
\hline & $x$ & 15.06 & 21.05 & & & 16.72 & 25.2 \\
\hline & $M$ & 19.36 & 28.00 & & & 30 & 40 \\
\hline
\end{tabular}

If these four variables are not measurable, discriminant function analysis cannot be used. However, identifications could be made using just the upper woody lamellae width $(A b)$ and the coefficient associated with the shape of the medial lamellae borders (coef_c; Figs. 8-10, Table 3), although the degree of confidence associated with any identification is not as high; in some cases the error can be as much as $19 \%$.

Other European populations of $P$. sylvestris (Sweeney, 2003) show smaller values for the same stomatal variables studied as in this work, especially the upper woody lamellae width $(A b)$ and the upper woody lamella length $(L b)$, indicating the intraspecific variability of these features. This is probably related to the different climatic conditions and biotopes in which they find themselves (Jones, 1992). Nevertheless, the values for the coefficient of slimness of the upper woody Iamellae (coef_b) - the only ratio that can be calculated from the data supplied by Sweeney (2003) - are quite close to those of the Iberian population studied (Table 4). This indicates that relationships between variables that are independent of the guard cell size - such as the coefficient associated with the shape of the medial lamellae borders (coef_c) and the coefficient associated with the relative size of the medial lamellae border width of a guard cell with respect to the distance between the external limits of the medial lamellae borders (coef_e) - are more stable at the species level and are therefore more taxonomically useful (García Amorena et al., 2006). No information is available on the European populations of $P$. uncinata.

The upper woody lamellae width $(A b)$, the upper woody lamella length $(L b)$, the coefficient associated with the shape of the medial lamellae borders (coef_c) and the coefficient associated with the relative size of the medial lamellae border width of a guard cell with respect to the distance between the external limits of the medial lamellae borders (coef_e) were therefore the variables that best distinguished between the Iberian populations of $P$. sylvestris and $P$. uncinata. The values of the upper woody lamellae width $(A b)$ and the upper woody lamella length $(L b)$ for $P$. uncinata were always larger than for $P$. sylvestris. The available values for these variables in European populations of $P$. sylvestits (Sweeney, 2003) are smaller than those of the Iberian $P$. uncinata population (Table 4).

Other authors assign much more importance to the $\alpha$ angle in taxonomic identification (Table 4), and it is commonly used to support the differentiation of certain genera (Florin, 1931; Trautmann, 1953; Hansen, 1995). Its limited ability to distinguish between the populations of the present study (both in PCA and discriminant analysis) shows its generic stability.

\section{Conclusions}

This study analyses the taxonomic stability and specificity of different cuticular and stomatal variables of two lberian populations of the genus Pinus.

The sun/shade factor appeared to have very little influence on the variables studied, increasing the potential diagnostic value of cuticular variables in future taxonomic studies.

Pinus syivestris and $P$. uncinata can be safely distinguished by the structure of their stomatal complexes, their subsidiary cells showing quite different shapes and arrangements. These differences are also visible in fossil material. Further, the diameter of the aperture of the epistomatic chamber of $P$. uncinata is significantly larger than that of $P$. sylvestris. However, a possible error of up to $9 \%$ exists within their overlap range ( $<5 \%$ outside this range).

Pinus sylvestris and $P$. uncinata can be differentiated by certain stoma characteristics, including the upper woody lamellae width $(A b)$ and the coefficient associated with the shape of the medial lamellae borders (coef_c), the coefficient associated with the relative size of the medial lamellae border width of the guard cells with respect to the distance between the external limits of the medial lamellae borders (coef_e), and the length of the upper woody lamella (Lb). All these 
variables can be measured in disperse stomata that appear in microscope preparations for pollen analysis. Among these variables, $A b$ stands out with its weight of 0.93 in the discriminant function obtained, as does coef_c which showed a weighting of 0.68 .

\section{Acknowledgements}

This research was performed with the kind help of the personnel of the Botany Teaching Unit (ETSI Montes, UPM, Spain). Helios Sainz (UAM) collected some Pinus uncinata material. Adrian Burton corrected the English. The study was partially supported by the Ministerio de Educación y Ciencia (project CGL-2006-02956/BOS) and Ministerio de Ciencia e Innovación (project CGL2008-06005/BOS). We thank the two anonymous reviewers of this paper for their constructive input

\section{Appendix A. Glossary of morphological terms (Trautmann, 1953; Stace, 1965; Hansen, 1995; Sweeney, 2003)}

Epistomatic chamber: cavity located over the guard cells (Fig. 2C). In many conifers the guard cells are very deeply sunken and completely overarched by the subsidiary cells. Thus, in surface view, their position is marked by a ring of subsidiary cells around a nearly circular pore (the aperture of the epistomatic chamber).

Medial lamella border: portion of the lamella bordering the stoma or opening, often thickened; close to a line drawn through the stems. Pore: epistomatic chamber opening.

Stem: the portion of the lamellae borders beginning at their junction and extending towards the poles away from the stoma.

Subsidiary cells: modified epidermal cells bordering the guard cells and comprising part of the stomatal complex.

Woody lamellae: lignified portion of the upper and lower wall of the stoma guard cells (Trautmann, 1953); upper and lower lamellae are present in Pinus stomata; the upper lamella is often thicker than the lower; lower woody lamellae are not often preserved in fossil pollen samples (Fig. 4).

\section{References}

Alvin, K.L., Dalby, D.H., Oladele, F.A., 1980. Numerical analysis of cuticular characters in Cupressaceae. In: Cutler, D.F., Alvin, K.L., Price, C.E. (Eds.), The Plant Cuticle. Academic Press, London, pp. 379-396.

Aubert, 5. Belet, J.M., Bouchette, A., Otto, T., Dedoubat, J.J., Fontugne, M., Jalut, G., 2004 Dynamique tardiglaciaire et holocène de la végétation à l'étage montagnard dans les Pyrénées centrales. Comptes Rendus Biologies 327, 381-388.

Barrón, E., Buades, A.r 2002. Aportaciones al estudio de la epidermis foliares en las especies vivientes de la familia Taxodiaceae (Coniferales, Coniferophyta). Boletín de la Real Sociedad Española de Historia Natural. Sección Biológica 97, 1-4.

Bennett, K.D., Parducci, L., 2006. DNA from pollen: principles and potential. Holocene $16(8), 1031-1034$

Boratynska, K., Bobowicz, M.A. 2001. Pinus uncinata Ramond taxonomy based on needle characters. Plant Systematics and Evolution 227, 183-194.

Boulter, M.C., 1971. Fine details of some fossil and recent conifer leaf cuticles. In: Heywood, V.H. (Ed.), Scanning Electron Microscopy: systematic and evolutionary applications. Academic Press, London, pp. 211-235.

Catalán Bachiller; G., 1991. Las regiones de procedencia de Pinus sylvestris L. y Pinus nigra Arn. Subsp. salzmanui (Dunal) Franco en España. ICONA. Ministerio de Agricultura, Pesca y Alimentación, Madrid.

Costa, M.r Morla, C., Sainz, H. (Eds.), 1997. Los Bosques Ibericos: una interpretacion geobotanica. Planeta, Madrid.

Del Río Merino, 5., 2000. Estudio paleobotánico del yacimiento de Herbosa (Burgos). Consideraciones paleofitogeográficas. Proyecto Fin de Camera, Escuela Técnica Superiol de Ingenieros de Montes. Universidad Politécnica de Madrid, Madrid.

Efron, B., 1982. The jacldknife, the bootstrap and other resampling plans. CBMS-NSF Regional Conference Series in Applied Mathematic. Pliladelphia.

Esau, K., 1982. Alatomía de las plantas con semilla. Hemisferio Sur S.A., Buenos Aires. Faegri, K, Iversen, J., 1989. Textbook of pollen analysis. New York, Chichester: Wiley.
Farjon, A., 1984. Pines. Drawings and descliptions of the genus Pinus. EJ. Brill, Leiden. Farjon, A., Styles, B.T., 1997. Flora Neotrópica, Monograph 75. Pinus (Pinaceae). The New York Botanical Garden, New York.

Florin. R., 1931. Untersuchungen zur Stammesgeschichte der Coniferales und Cordaitales. Kungliger Svenska Vetenskapsakademien Handlingar 10 (1), Stockholm.

Florin, R., 1939. Die Koniferen del oberkarbons und des uneteren Perms IV Palaeontographica B 85, 176-243.

Franco Múgica, F., Garćía Antón, M., Maldonado Ruiz, l., Morla Juaristi, C., Sainz Ollero, $\mathrm{H}$., 2001. The Holocence history of the Pinus forests on the Spanish Northem Meseta. Holocene 11 (3), 343-358.

García-Amorella, I., Wagner, F., van Hoof, T., Gómez Manzaneque, F., 2006. Stomata responses in deciduous oaks from southern Europe to the anthropogenic atmospheric $\mathrm{CO}_{2}$ increase; refining the stomatal-based $\mathrm{CO}_{2}$ proxy. Review of Palaeobotany and Palynology 141 (3-4), 303-312.

Gaussen, H., Heywood, V.H., Chater, AO., 1964. Pinus L. In: Tutin, T.G., Heywood, V.H. Burges, N.A., Valentine, D.H., Walter, S.M., Webb, D.A. (Eds.). Flora Europaea. Lycopodiaceae to Platanaceae, vol. 1. University Press, Cambridge, pp. 32-35.

Hansen. B., 1995. Conifer stomate analysis as a paleoecological tool: an example from the Hudson Bay Lowlands. Canadian Journal of Botany 73, 244-252.

Hansen, M., Hurwitz, W., Madow, W., 1953. Sample survey. Methods and Theory, vol 1. Wiley, New York.

Huntley, B., Birks, H.J.B., 1983. An atlas of past and present pollen maps of Europe: 0-13000 years ago. Cambridge University Press, Cambrige.

Jones, H., 1992. Plants and microclimate. Cambridge University Press, Cambridge.

Kerp, H., 1990. The study of fossil gymnosperms by means of cuticular analysis. Palaios 5. 548-569.

Kim, K., Whang, S.S., Hill, R.S., 1999. Cuticle mictomorphology of leaves of Pimus (Pinaceae) in east and south-east Asia. Botanical Journal of the Linnean Society 129 55-74.

Madrigal Collazo, A., Álvarez Gonzalez, J.G., Rodríguez Soalleiro, R., Rojo Alboreca, A., 1999. Tablas de Producción para los Montes Espanoles. Fundación Conde del Valle de Salazar, Madrid.

Martín Albertos, S., Díaz-Fernández, P.M., De Miguel y Del Ángel, J., 1998. Regiones de Procedencia de las Especies Forestales Espanolas. Géneros Abies, Fagus, Pinus y Qziercas. Organismo Autónomo Parques Nacionales, Madrid.

Mirov, N.T., 1967. The Genus Pinus. The Ronald Press Company, New York.

Rios, 5., 1977. Métodos estadísticos. Del Castillo, S.A., Madrid.

Rubiales, J.M., García-Amorena, I., Génova, M., Gómez Manzaneque, F., Morla, C., 2007 The Holocene history of highland pine forests in a submediterranean mount ain: the case of Gredos mountain range (Iberian Central range, Spain). Ouaternary Science Reviews 26, 1759-1770.

Semada Hierro, R. Montero, G., Reque Kilchenmann, JA. (Eds.), 2008. Compendio de selvicultura aplicada en España. INIA, Madrid.

Scliweingruber; F.H., 1990. Anatomie europäischer Hölzer/Anatomy of European woods. Swiss Federal Institute for Forest, Snow and Landscape Research, Birmensdorf, Bern.

Stace, C.A., 1965. Cuticular studies as an aid to plant taxonomy. The Bulletin of the British Museum, Natural History. Botany Series 4 (1), 3-78.

Stružková, D., 2002. The Cuticular Analysis - a method to distinguish the needles of Pinus syivestris L (Scots pine) from those of Pinus mugo Tura s str (Mountain pine). Vegetation History and Archaeobotany 11, 241-246.

Sweeney. CA. 2003. A key for the identification of stomata of the native conifers of Scandinavia. Review of Palaeobotany and Palynology 128, 281-290.

Theobald, W.L., Kralhulik, J.L., Rollins, R.C., 1979. Trichome description and classification. In: Metcalfe, C.R. Chalk, L. (Eds.). Anatomy of the Dicotiledons V. I. Systematic Anatomy of Leaf and Stem, with a brief history of the subject. Clarendon, Oxford.

Tichá, I., 1982, Photosynthetic characteristics during ontogenesis of leaves: 7 . Stomata density and sizes. Photosynthetica 16 (2), 375-471.

Trautmann, W. 1953. Zur Unterscheidung fossiler Splatöffnugen der mitteleuropäischen Coniferen. Flora 140, 523-533.

Turner, C. Hannon, G.E., 1988. Vegetational evidence for late Quatemary climatic changes in southwest Europe in relation to the influence of the north Atlantic Ocean. Philosophical Transactions of the Royal Society of London. B 318, 451-485.

Whang. 5.5. Pak, J.H., Hill, R.S., Kim, K., 2001. Cuticle micromorphology of leaves of Pinus (Pinaceae) from Mexico and Central America. Botanical Journal of the Linnean Society 135 (4), 349-373.

Whang, S.S., Kim, K. Hill, R.S. 2004. Cuticle micromolphology of leaves of Pinus (Pinaceae) from North America. Botanical loumal of the Linnean Society 144 (3). 303-320.

Yoshie, F., Sakai, A., 1985. Types of Florin rings, distributional patterns of epicuticular wax, and their relationships in the genus Pinus. Canadian Joumal of Botany 63. 2150-2158.

Yu, Z., 1997. Late Quatemary paleoecology of Thuja and junipens (Cupressaceae) at Clawford Lake, Ontario, Canada; pollen, stomata and macrofossils. Review of Palaeobotany and Palynology 96, 241-254. 